\title{
GAMBARAN TINGKAT KEPUASAN PUS TERHADAP PELAYANAN KONSELING KB DI PMB BIDAN C KECAMATAN CIHIDEUNG BALONG KOTA TASIKMALAYA TAHUN 2016
}

\author{
Hapi Apriasih, SST, M.Kes \\ py.anbyan@gmail.com
}

\section{Ai Dida Lisnawati}

\author{
Sekolah Tinggi Ilmu Kesehatan (STIKes) Respati Tasikmalaya
}

\section{A. ABSTRAK}

Konseling merupakan aspek yang sangat penting dalam Pelayanan Keluarga Berencana dan Kesehatan Reproduksi. Konseling merupakan peran petugas membantu dalam memlilih dan memutuskan jenis kontrasepsi yang digunakan sesuai pilihannya, konseling yang baik akan membantu klien dalam menggunakan kontrasepsi lebih lama dan meningkatkan keberhasilan KB.

Jenis penelitian ini adalah diskriptif atau menggambarkan dengan variabel gambaran tingkat kepuasan PUS terhadap pelayanan konseling KB. Populasi dan sampel sejumlah 45 PUS mendapatkan pelayanan KB di BPM Bidan C Kota Tasikmalaya periode bulan September yang dilakukan dengan teknik sampling jenuh atau mengambil keseluruhan populasi dengan menggunakan instrumen kuesioner, analisis data menggunakan tabel distribusi frekuensi.

Hasil penelitian menunjukan Sebagian besar responden berumur $>35$ tahun yaitu sebanyak 35 Responden (67\%), mempunyai latar belakang Pendidikan Menengah sebanyak 19 Responden (43\%), sebagai Ibu Rumah Tangga yaitu sebanyak 18 Responden (41\%), multipara yaitu sebanyak 20 Responden (44\%), menggunakan kontrasepsi suntik yaitu sebanyak 20 Responden (45\%), tidak puas dalam aspek keandalan yaitu sebanyak 20 Responden (44\%), tidak puas dalam aspek daya tanggap yaitu sebanyak 18 Responden (41\%), tidak puas dalam aspek jaminan kepastian yaitu sebanyak 18 Responden (44\%). puas dalam aspek empati yaitu sebanyak 20 Responden (45\%), tidak puas dalam aspek bukti langsung yaitu sebanyak 20 Responden (45\%).

Dapat disimpulkan bahwa PUS yang mendapatkan pelayanan konseling KB sebagian besar responden tidak puas terhadap pelayanan konseling KB dalam aspek keandalan, daya tanggap, jaminan kepastian dan bukti langsung, meski demikian dalam hal empati sudah dirasa puas. Dilihat dari penggunaan kontrasepsi masih banyak akseptor yang tidak sesuai dalam menggunakan alat kontrasepsi, hal ini menunjukan perlunya konseling yang lebih aktif sesuai dengan pedoman konseling KB, konseling dilakukan sebelum klien memilih suatu kontrasepsi. Oleh karena itu perlu peningkatan mutu pelayanan mengenai Konseling KB yang akan membantu klien dalam memilih kontrasepsi yang sesuai dengan kebutuhannya.

\section{Kata Kunci : Kepuasan, Konseling KB}

Kepustakaan : 14 (2006-2016) 


\section{A. PENDAHULUAN}

Saat ini Indonesia merupakan negara dengan jumlah penduduk terbesar ke 4 di dunia setekah Amerika Serikat, dengan laju pertumbuhan penduduk 1,26 \% pada tahun 2016. Jika laju pertumbuhan penduduk tidak dapat dikendalikan maka mengakibatkan banyak penduduk yang menderita kekurangan makan dan gizi sehingga tingkat kesehatan memburuk dan kekurangan lapangan pekerjaan. Untuk menghindari terjadinya ledakan penduduk tersebut, maka perlu di lakukan akselerasi revitalisasi yang terkait dengan capaian sasaran Millenium Development Goals (MDGs) yaitu meningkatkan derajat kesehatan ibu serta tercapainya akses universal terhadap layanan kesehatan reproduksi sehingga dapat menurunkan angka kelahiran atau Total Fertility Rate (TFR) mencapai level sebesar 2,1. (Kemenkes RI, 2012)

Pemerintah Indonesia melalui program Keluarga Berencana telah menerapkan suatu kebijakan kependudukan yang diharapkan pada zero population growth. Konseling merupakan aspek yang sangat penting dalam Pelayanan Keluarga Berencana dan Kesehatan Reproduksi. Konseling merupakan peran petugas membantu dalam memlilih dan memutuskan jenis kontrasepsi yang digunakan sesuai pilihannya, konseling yang baik akan membantu klien dalam menggunakan kontrasepsi lebih lama dan meningkatkan keberhasilan KB. (Saifuddin, 2014)

Kelangsungan pemakaian kontrasepsi merupakan pemakaian alat kontrasepsi yang berlangsung secara terus menerus. Untuk mencapai kelangsungan pemakaian kontrasepsi ini dibutuhkan pelayanan keluarga berencana (KB) yang berkualitas. Salah satu elemen kualitas pelayanan keluarga berencana adalah informasi yang diberikan kepada klien dan mekanisme follow-up dan kontak kembali. Informasi yang diberikan kepada klien ini terdapat dalam proses konseling kontrasepsi. Konseling kontrasepsi merupakan aspek yang sangat penting dalam pelayanan keluarga berencana dan kesehatan reproduksi. Konseling merupakan aspek yang penting dalam Keluarga Berencana (KB) dan Kesehatan Reproduksi (KR). Dengan melakukan konseling petugas kesehatan $\mathbf{1}$.

klien dalam memilih dan me jenis kontrasepsi yang digunakan sesua pilihannya. (Sulistyawati, 2013)

Hal tersebut sesuai dengan standar kon bidan yang ke dua berdasarkan keputusan

Kesehatan Republik Indonesia 369/MENKES/SK/III/2007 tentang standa1 . bidan. Para bidan diharapkan memberikan asuhan yang bermutu tinggi, pendidikan kesehatan yang tanggap terhadap budaya dan pelayanan menyeluruh di masyarakat dalam rangka untuk meningkatkan kehidupan keluarga yang sehat, perencanaan kehamilan dan kesiapan orang tua. Dengan pengetahuan dasar metode konseling bagi wanita dalam memilih metode kontrasepsi.

Menurut BKKBN 2014 penggunaan kontrasepsi paling banyak adalah suntik dengan persentase sebesar 48,56\%, sementara penggunaan kontrasepsi metode jangka panjang hanya $18,7 \%$. Data tersebut menunjukan bahwa penggunaan kontrasepsi jangka panjang kurang diminati padahal metode tersebut efektif dalam mencegah kehamilan sehingga diperlukan upaya untuk dapat memberikan pemahaman pus terhadap penggunaan kontrasepsi yang sesuai (infodatin 2014).

Berdasarkan studi pendahuluan di BPM Bidan C pada bulan September 2016 sebanyak 45 orang, tidak ada yang menggunakan MKJP sebagian besar menggunakan kontrasepsi suntik. Dalam penelitian ini, peneliti hanya membatasi pada sajauh mana kepuasan pengguna dalam konseling pelayanan KB.

Berdasarkan uraian dari latar belakang diatas maka penulis bermaksud untuk melakukan penelitian dengan judul gambaran tingkat kepuasan PUS terhadap pelayanan Konseling KB di BPM Bidan C di Kota Tasikmalaya Periode Bulan September Tahun 2016.

\section{B. METODOLOGI PENELITIAN \\ 1. Desain Penelitian}

Desain penelitian yang digunakan dalam penelitian ini adalah deskriptif, dengan pendekatan observasional yaitu penelitian yang dilakukan hanya mendeskripsikan dari variabel yang diobservasi oleh peneliti.

\section{Waktu dan Tempat Penelitian}

Penelitian ini telah dilaksanakan pada bulan Oktober s.d November 2016. Penelitian ini telah dilaksanakan di Kecamatan Cihideung Balong Kota Tasikmalaya.

\section{Populasi dan Sampel}

Populasi dalam penelitian ini adalah ibu-ibu pasangan usia subur yang menggunakan kontrasepsi atau pun yang tidak menggunakan kontrasepsi di BPM Bidan C di Kota Tasikmalaya pada bulan September sebanyak 45 orang. Pada penelitian ini yang menjadi sampel adalah total populasi yaitu ibuibu pasangan usia subur yang menggunakan kontrasepsi atau pun yang tidak menggunakan 
kontrasepsi di BPM Bidan C di Kota Tasikmalaya pada bulan September sebanyak 45 orang

\section{Prosedur Pengambilan Data}

Pengambilan data dalam penelitian ini berupa data primer untuk mendapatkan data kepuasan pelayanan konseling KB.

\section{Instrumen Penelitian}

Dalam penelitian ini instrument penelitian yang digunakan adalah kuesioner dengan skala Likert tentang kepuasan terhadap pelayanan konseling $\mathrm{KB}$ dengan jumlah item 20.

\section{Pengolahan dan Analisis Data}

Analisa univariat dilakukan untuk mendeskipsikan variabel penelitian yaitu Karakteristik responden berdasarkan umur, pendidikan, pekerjaan, paritas, penggunaan kontrasepsi dan kepuasan pelayanan Konseling KB.

\section{HASIL PENELITIAN}

Pada bagian ini akan disajikan hasil penelitian mengenai "Gambaran Tingkat Kepuasan PUS terhadap pelayanan konseling KB". Penelitian ini dilaksanakan pada bulan Oktober- November 2016 dan pengambilan data dilakukan dengan penyebaran kuesioner sejumlah 45 kuesioner dan kuesioner yang disebarkan seluruhnya kembali, baru kemudian dilakukan pengolahan data kemudian dilakukan analisa. Sebelum menjelaskan hasil penelitian, terlebih dahulu akan dijelaskan mengenai karakteristik responden sebagai berikut :

1. Karakteristik Responden Berdasarkan Umur

Tabel 4.1 Distribusi Frekuensi Responden Berdasarkan Umur di Kecamatan Cihideung Balong, Kota Tasikmalaya Tahun 2016

\begin{tabular}{ccc}
\hline Kategori & Frekuensi & Persentase \\
\hline$<20$ & 4 & 8 \\
$20-35$ & 11 & 25 \\
$>35$ & 30 & 67 \\
\hline Jumlah & 45 & 100 \\
\hline
\end{tabular}

Berdasarkan Tabel 4.1 menunjukkan sebagian besar responden berumur lebih dari 35 tahun yaitu $67 \%$.

2. Karakteristik Responden Berdasarkan Pendidikan Tabel 4.2 Distribusi Frekuensi Responden Berdasarkan Pendidikan di Kecamatan Cihideung Balong, Kota Tasikmalaya Tahun 2016

\begin{tabular}{lcc}
\hline \multicolumn{1}{c}{ Kategori } & Frekuensi & Persentase \\
\hline Dasar & 5 & 11 \\
SMP & 10 & 22 \\
Menengah & 19 & 43
\end{tabular}

\begin{tabular}{ccc}
\hline Tinggi & 11 & 24 \\
\hline Jumlah & 45 & 100 \\
\hline
\end{tabular}

Berdasarkan Tabel 4.2 menunjukkan sebagian besar pendidikan responden menengah yaitu 19 (43\%)

3. Karakteristik Responden Berdasarkan Pekerjaan Tabel 4.3 Distribusi Frekuensi Responden Berdasarkan Pekerjaan di Kecamatan Cihideung Balong, Kota Tasikmalaya Tahun 2016

\begin{tabular}{ccc}
\hline Kategori & Frekuensi & Persentase \\
\hline Tani & 8 & 17 \\
Swasta & 15 & 33 \\
IRT & 18 & 41 \\
PNS & 4 & 9 \\
\hline Jumlah & 45 & 100 \\
\hline
\end{tabular}

Berdasarkan Tabel 4.3 menunjukkan sebagian besar pekerjaan responden IRT yaitu 18 orang (41\%)

4. Karakteristik Responden Berdasarkan Paritas Tabel 4.4 Distribusi Frekuensi Responden Berdasarkan Paritas di Kecamatan Cihideung Balong, Kota Tasikmalaya Tahun 2016

\begin{tabular}{ccc}
\hline Kategori & Frekuensi & Persentase \\
\hline Primipara & 7 & 16 \\
Multipara & 20 & 44 \\
Grandemultipara & 18 & 40 \\
\hline Jumlah & 45 & 100 \\
\hline
\end{tabular}

Berdasarkan Tabel 4.4 menunjukkan sebagian besar paritas responden multipara yaitu 20 orang (44\%)

5. Karakteristik Responden Berdasarkan Penggunaan Kontrasepsi

Tabel 4.5 Distribusi Frekuensi Responden Berdasarkan Penggunaan kontrasepsi di Kecamatan Cihideung Balong, Kota Tasikmalaya Tahun 2016

\begin{tabular}{lcc}
\hline \multicolumn{1}{c}{ Kategori } & Frekuensi & Persentase \\
\hline Suntik & 20 & 45 \\
Pil & 15 & 33 \\
Kondom & 6 & 13 \\
Sederhana & 4 & 9 \\
\multicolumn{1}{c}{ Jumlah } & 45 & 100 \\
\hline
\end{tabular}


Berdasarkan Tabel 4.5 menunjukkan sebagian besar responden menggunakan KB suntik yaitu 20 orang $(45 \%)$

6. Kepuasan Responden Terhadap Pelayanan Konseling KB

a. Aspek Keandalan (reliability)

Tabel 4.6 Distribusi Frekuensi Responden Berdasarkan Kepuasan aspek Keandalan (reliability) Terhadap Pelayanan Konseling KB di Kecamatan Cihideung Balong, Kota Tasikmalaya Tahun 2016

\begin{tabular}{ccc}
\hline Kategori & Frekuensi & Persentase \\
\hline Sangat Tidak Puas & 5 & 11 \\
Tidak Puas & 20 & 44 \\
Puas & 15 & 33 \\
Sangat Puas & 5 & 11 \\
\hline Jumlah & 45 & 100 \\
\hline
\end{tabular}

Berdasarkan distribusi frekuensi sebagian besar responden tidak puas dalam aspek keandalan yaitu sebanyak 20 Responden (44\%).

b. Aspek Daya tanggap (Responsiveness)

Tabel 4.7 Distribusi Frekuensi Responden Berdasarkan Kepuasan aspek Daya tanggap (Responsiveness) Terhadap Pelayanan Konseling KB di Kecamatan Cihideung Balong, Kota Tasikmalaya Tahun 2016

\begin{tabular}{ccc}
\hline Kategori & Frekuensi & Persentase \\
\hline Sangat Tidak Puas & 15 & 33 \\
Tidak Puas & 18 & 41 \\
Puas & 10 & 22 \\
Sangat Puas & 2 & 4 \\
\hline Jumlah & 45 & 100 \\
\hline
\end{tabular}

Berdasarkan distribusi frekuensi sebagian besar responden tidak puas dalam aspek daya tanggap yaitu sebanyak 18 Responden (41\%).

c. Aspek Jaminan kepastian (Assurance)

Tabel 4.8 Distribusi Frekuensi Responden Berdasarkan Kepuasan aspek Jaminan kepastian (Assurance), Terhadap Pelayanan Konseling KB di Kecamatan Cihideung Balong, Kota Tasikmalaya Tahun 2016

\begin{tabular}{ccc}
\hline Kategori & Frekuensi & Persentase \\
\hline Sangat Tidak Puas & 10 & 22 \\
Tidak Puas & 9 & 20
\end{tabular}

\begin{tabular}{ccc}
\hline Puas & 20 & 44 \\
Sangat Puas & 6 & 14 \\
\hline Jumlah & 45 & 100 \\
\hline
\end{tabular}

Berdasarkan distribusi frekuensi sebagian besar responden puas dalam aspek jaminan kepastia yaitu sebanyak 18 Responden (44\%).

d. Aspek Empati (Emphaty)

Tabel 4.9 Distribusi Frekuensi Responden Berdasarkan Kepuasan aspek Empati (Emphaty) Terhadap Pelayanan Konseling KB di Kecamatan Cihideung Balong, Kota Tasikmalaya Tahun 2016

\begin{tabular}{ccc}
\hline Kategori & Frekuensi & Persentase \\
\hline Sangat Tidak Puas & 4 & 9 \\
Tidak Puas & 6 & 13 \\
Puas & 15 & 33 \\
Sangat Puas & 20 & 45 \\
\hline Jumlah & 45 & 100 \\
\hline
\end{tabular}

Berdasarkan distribusi frekuensi sebagian besar responden puas dalam aspek empati yaitu sebanyak 20 Responden (45\%).

e. Aspek Bukti langsung (Tangible)

Tabel 4.10 Distribusi Frekuensi Responden Berdasarkan Kepuasan aspek Bukti langsung (Tangible) Terhadap Pelayanan Konseling KB di Kecamatan Cihideung Balong, Kota Tasikmalaya Tahun 2016

\begin{tabular}{ccc}
\hline Kategori & Frekuensi & Persentase \\
\hline Sangat Tidak Puas & 15 & 33 \\
Tidak Puas & 20 & 45 \\
Puas & 6 & 13 \\
Sangat Puas & 4 & 9 \\
\hline Jumlah & 45 & 100 \\
\hline
\end{tabular}

Berdasarkan distribusi frekuensi sebagian besar responden tidak puas dalam aspek bukti langsung yaitu sebanyak 20 Responden (45\%).

\section{E. PEMBAHASAN \\ 1. Karakteristik \\ Berdasarkan Umur \\ Responden}

Berdasarkan distribusi frekuensi sebagian besar responden berumur $>35$ tahun yaitu sebanyak 35 Responden (67\%). Usia menurut Elisabet (1995) dalam Nursalam (2001) yaitu umur adalah usia individu yang terhitung mulai saat dilahirkan sampai saat berulang tahun. Pendapat lain mengemukakan bahwa semakin cukup umur, tingkat kematangan dan kekuatan seseorang akan 
lebih matang dalam berfikir dan berkerja dari segi kepercayaan masyarakat. Seseorang yang dewasa akan lebih percaya diri dari orang yang belum cukup kedewasaanya. Menurut Long (1996) dalam Nursalam (2001), yaitu semakin tua umur seseorang semakin konstruksi dalam menggunakan koping terhadap masalah yang dihadapi. Semakin muda umur seseorang dalam menghadapi masalah maka akan sangat mempengaruhi konsep dirinya. Umur dipandang sebagai suatu keadaan yang menjadi dasar kematangan dan perkembangan seseorang. Kematangan individu dapat dilihat langsung secara objektif dengan umur, sehingga berbagai proses pengalaman, pengetahuan, ketrampilan, kemandirian terkait sejalan dengan bertambahnya umur individu.

Sedangkan menurut Setionegoro (1979) dalam Nursalam (2001) mengatakan bahwa umur $<20$ tahun adalah umur belum dewasa, 20-35 tahun dewasa muda, sedangkan umur $>35$ tahun adalah dewasa penuh. Pada umumnya umur akan mempengaruhi seseorang dalam menentukan pemilihan alat kontrasepsi karena biasanya ibu dengan usia muda (baru pertama kali menggunakan alat kontrasepsi) akan cenderung memilih alat kontrasepsi yang kebanyakan orang pakai.

\section{Karakteristik responden berdasarkan pendidikan}

Berdasarkan distribusi frekuensi sebagian besar responden mempunyai latar belakang Pendidikan Menengah sebanyak 19 Responden (43\%). Menurut Nursalam dalam Dewi.M (2011), pendidikan adalah suatu usaha untuk mengembangkan kepribadian dan kemampuan di dalam dan di luar sekolah dan berlangsung seumur hidup. Pendidikan mempengaruhi proses belajar, makin tinggi pendidikan seseorang makin mudah orang tersebut untuk menerima informasi. Dengan pendidikan tinggi maka seseorang akan cenderung lebih mudah untuk mendapatkan informasi, baik dari orang lain maupun dari media massa.

Menurut Suryadi (2000), dalam Notoatmodjo (2003), kaitan proses pendidikan dengan pembangunan khususnya pembangunan manusia, dijelaskan bahwa pendidikan dapat diperoleh melalui jenjang pendidikan yaitu pendidikan prasekolah, pendidikan dasar, pendidikan menengah, dan pendidikan tinggi, lebih lanjut, jenjang (tingkat) pendidikan terdiri atas pendidikan prasekolah, pendidikan dasar, pendidikan menengah, dan pendidikan tinggi. Tingkat pendidikan adalah lamanya pendidikan seseorang yang didasarkan atas kemampuan dan kesempatan seseorang mengikuti satuan pendidikan yang menyelenggarakan kegiatan belajar mengajar.

\section{Karakteristik responden berdasarkan pekerjaan}

Berdasarkan distribusi frekuensi sebagian besar responden sebagai Ibu Rumah Tangga yaitu sebanyak 18 Responden (41\%). Menurut Thomas yang dikutip oleh Nursalam (2003), pekerjaan adalah keburukan yang harus dilakukian terutama untuk menunjang kehidupannya dan kehidupan keluarga. Pekerjaan bukanlah sumber kesenangan, tetapi lebih banyak merupakan cara mencari nafkah yang membosankan,berulang dan banyak tantangan. Sedangkan bekerja umumnya merupakan kegiatan yang menyita waktu. Bekerja bagi ibu-ibu akan mempunyai pengaruh terhadap kehidupan keluarga.

\section{Karakteristik Responden berdasarkan Paritas}

Berdasarkan hasil penelitian bahwa sebagian besar responden mempunyai anak lebih dari 1 , hal tersebut menunjukan bahwa dalam hal memperoleh keturuan sudah lebih dari cukup, dan seharusnya sudah mempunyai pengalaman dalam penggunaan kontrasepsi dan akan memilih kontrasepsi yang sesuai, hal ini sesuai dengan Notoatmodjo (2014) semakin banyak paritas ibu maka pengetahuannya akan semakin tinggi karena ada kaitannya dengan pengaruh pengalaman sendiri.

\section{Karakteristik Penggunaan Kontrasepsi Berdasarkan Alat Kontrasepsi yang Digunakan}

Berdasarkan distribusi frekuensi sebagian besar responden menggunakan kontrasepsi suntik yaitu sebanyak 20 Responden (45\%), dan $40 \%$ dengan paritas grandemultipara, seharusnya pada kondisi paritas demikian pasangan usia subur sudah dapat menentukan upaya untuk dapat menghentikan kehamilan yaitu dengan penggunaam kontrasepi yang efektif untuk menghentikan kehamilan, karena pada kondisi tersebut banyak dampak yang bisa terjadi baik baik ibu maupun pada bayi, sejalan dengan hasil penelitian Dian Gusta Anggraini 2015 bahwa ada hubungan yang bermakna antara paritas, riwayat kehamilan sebelumnya, riwayat persalinan sebelumnya dengan kehamilan risiko tinggi, dikarenakan fungsi uterusnya sudah berkurang seiring dengan menuanya organ-organ pada ibu bersalin. Dampak kehamilan risiko tinggi akibat dari 
paritas < 3 dan > 3 yang di alami oleh ibu hamil jika tidak segera ditanggulangi, akan mengalami perdarahan, anak lahir dengan berat badan rendah dan tidak sedikit berakhir dengan pesalinan dengan operasi Caesar.

\section{Tingkat Kepuasan Pus Terhadap Pelayanan Konseling KB.}

Berdasarkan distribusi frekuensi sebagian besar responden tidak puas dalam aspek keandalan yaitu sebanyak 20 Responden (44\%), sebagian besar responden tidak puas dalam aspek daya tanggap yaitu sebanyak 18 Responden (41\%), sebagian besar responden puas dalam aspek jaminan kepastia yaitu sebanyak 18 Responden (44\%), sebagian besar responden puas dalam aspek empati yaitu sebanyak 20 Responden (45\%), sebagian besar responden tidak puas dalam aspek bukti langsung yaitu sebanyak 20 Responden (45\%).

Berdasarkan data tersebut dapat digambarkan bahwa pus merasa tidak puas dalam aspek keandalan daya tanggap dan aspek bukti langsung tetapi merasa puas dalam aspek empati, terhadap pelayanan konseling KB yang dilakukan oleh bidan C. Ketidakpuasan PUS dipengaruhi oleh kurangnya konseling yang diberikan oleh tenaga kesehatan sehingga kurang tepatnya seseorang dalam menentukan kontrasepsi yang cocok dengan dirinya sehingga dapat memicu tingginya ketidak puasan seseorang terhadap alat kontrasepsi yang digunakan.

Kepuasan adalah perasaan senang atau kecewa seseorang yang dialami setelah membandingkan antara persepsi kinerja atau hasil suatu produk dengan harapanharapannya (Kotler, 2003).Kepuasan sebagai tingkat perasaan seseorang setelah membandingkan kinerja atau hasil yang dirasakannya dengan harapannya. Tingkat kepuasan merupakan fungsi dari perbedaan antara kinerja yang dirasakan dengan harapan. (Suprapto, 2001) Sebenarnya untuk memberikan layanan yang memuaskan pelanggan yakni dengan memberikan kenyataan (perception) sesuai harapan (expectation) pelanggan Sebaliknya, jika kenyataan lebih kecil dibandingkan dengan harapan, maka pelanggan akan menjadi kecewa, minimal kualitas pelayanan yang diberikan kepada pelanggan melebihi apa yang diharapkan oleh pelanggan.

\section{F. KESIMPULAN}

Berdasarkan hasil penelitian dan pembahasan, maka dapat disimpulkan sebagai berikut :

1. Sebagian besar responden berumur $>35$ tahun yaitu sebanyak 35 Responden (67\%).

2. Sebagian besar responden mempunyai latar belakang Pendidikan Menengah sebanyak 19 Responden (43\%).

3. Sebagian besar responden sebagai Ibu Rumah Tangga yaitu sebanyak 18 Responden (41\%).

4. Sebagian besar responden multipara yaitu sebanyak 20 Responden (44\%).

5. Sebagian besar responden menggunakan kontrasepsi suntik yaitu sebanyak 20 Responden $(45 \%)$

6. Sebagian besar responden tidak puas dalam aspek keandalan yaitu sebanyak 20 Responden (44\%).

7. Sebagian besar responden tidak puas dalam aspek daya tanggap yaitu sebanyak 18 Responden $(41 \%)$.

8. Sebagian besar responden puas dalam aspek jaminan kepastia yaitu sebanyak 18 Responden (44\%).

9. Sebagian besar responden puas dalam aspek empati yaitu sebanyak 20 Responden (45\%).

10. Sebagian besar responden tidak puas dalam aspek bukti langsung yaitu sebanyak 20 Responden $(45 \%)$.

\section{G. DAFTAR PUSTAKA}

1. Arikunto, Suharsini. (2006). Prosedur Penelitian Satuan Pendekatan Praktik.

2. BKKBN. (2009). Keluarga Berencana http://www.bkkbn.go.id/_layouts/OSSSearchRes ults.aspx?k=keluarga

berencanawww.bkkbn.go.id (diakses tanggal 25 April 2016).

3. Daryanto. (2011). Sari Kuliah Manajemen Pemasaran. Bandung: Satu Nusa

4. Dien Gusta Anggraini Nursal, Rise Marisa Satri. 2015 KEHAMILAN RISIKO TINGGI DI PUSKESMAS LUBUK GADANG KABUPATEN SOLOK SELATAN. Jurnal Kesehatan Masyarakat Andalas, file:///D:/Downloads/414-1047-1-PB.pdf.

Diakses 15 Desember 2016.

5. Handayani, Sri. (2011). Buku Ajar Pelayanan Keluarga Berencana. Yogyakarta:

6. Hidayat, Aziz Alimul. (2011). Metode Penelitian Kebidanan Teknik Analisis Data. Jakarta: Salemba Medika

7. Infodatin, 2014, Pusat Data dan informasi Situasi dan Analisis Keluarga Berencana, Kementrian Kesehatan RI, Jakarta

8. Sugiyono. (2011). Statistika untuk Penelitian. 
Bandung: Alfabeta

9. Mamik. (2010). Organisasi dan

Manajemen Pelayanan Kesehatan dan

Kebidanan. Surabaya: Prins Media Publishing

10.Manuaba, dkk. (2012). Ilmu Penyakit Kandungan dan KB untuk Pendidikan Bidan. Jakarta : EGC

11.Notoatmodjo, (2010). Metodologi Penelitian. Jakarta : Rineka Cipta.

12.Nursalam. (2008). Konsep dan Penerapan Metodologi Penelitian Ilmu Keperawatan.

Jakakarta : Salemba Medika Pustaka Rihama

13.Saifuddin, Abdul Bari. (2006). Buku Panduan Praktis Pelayanan Kontrasepsi. Jakarta : PT Bina Pustaka Sarwono Prawirohardjo

14.Supranto.J. (2011). Pengukuran Tingkat Kepuasan Pelanggan. Jakarta: Rineka Cipta 